\title{
Pengaruh Regulasi Diri dan Coronavirus Anxiety terhadap Mental Well- being pada Wanita Karier yang Menikah
}

\author{
LAILI FARISTIN SUKMA \& HERISON PANDAPOTAN PURBA* \\ Departemen Psikologi Industri dan Organisasi, Fakultas Psikologi Universitas Airlangga
}

\begin{abstract}
ABSTRAK
Fenomena wanita karier yang bertambah setiap tahunnya menjadikan wanita memiliki beberapa konflik peran yang menyebabkan adanya penurunan kesejahteraan mental, apalagi selama pandemi COVID-19 seperti saat ini. Tujuan penelitian ini yaitu untuk mengetahui adanya pengaruh regulasi diri dan coronavirus anxiety terhadap mental well-being pada wanita karier yang menikah. Penelitian ini adalah penelitian kuantitatif yang melibatkan 107 wanita karier yang menikah. Pengumpulan data dilakukan melalui survei daring yang tersusun atas Self-Regulation Scale (SRS), Coronavirus Anxiety Scale (CAS), serta The Warwick-Edinburgh Mental Well-being Scale (WEMWBS). Analisis data menggunakan teknik regresi linear berganda dengan bantuan program IBM SPSS 22.0 for Windows. Hasil penelitian menunjukkan adanya pengaruh yang signifikan antara regulasi diri dan coronavirus anxiety terhadap mental well-being pada wanita karier yang menikah, baik secara simultan maupun parsial.
\end{abstract}

Kata kunci: coronavirus anxiety, kesejahteraan mental, regulasi diri, wanita karier

\begin{abstract}
The phenomenon of career women has increased every year makes women have several role conflicts that cause a decrease in mental well-being, especially during the COVID-19 pandemic nowadays. This study aims to determine the influences of self-regulation and coronavirus anxiety towards mental wellbeing viewed from married career women. The research used quantitative study involving 107 married career women. Data collection was carried out through an online survey which was composed of The Self-Regulation Scale (SRS), The Coronavirus Anxiety Scale (CAS). and The Warwick-Edinburgh Mental Well-being Scale (WEMWBS). The data analysis in this study used multiple linear regression techniques with the help of the IBM SPSS 22.0 for Windows program. The results showed that there was a significant effect between self-regulation and coronavirus anxiety on mental well-being in married career women, either simultaneously or partially.
\end{abstract}

Keywords: career women, coronavirus anxiety, mental well-being, self-regulation

Buletin Penelitian Psikologi dan Kesehatan Mental (BRPKM), 2021, Vol. 1(1), 252-261

*Alamat korespondensi: Fakultas Psikologi Universitas Airlangga, Kampus B Universitas Airlangga Jalan Airlangga 4-6 Surabaya 60286. Surel: herison.purba@psikologi.unair.ac.id

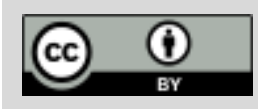

Naskah ini merupakan naskah dengan akses terbuka dibawah ketentuan the Creative Common Attribution License (CC-BY-4.0) (http://creativecommons.org/licenses/by/4.0), sehingga penggunaan, distribusi, reproduksi dalam media apapun atas artikel ini tidak dibatasi, selama sumber aslinya disitir dengan baik. 


\section{P E N D A H U L U A N}

Partisipasi kerja pada wanita mengalami kenaikan secara substansial di seluruh dunia. Secara global pada tahun 2012 tingkat partisipasi wanita karier sebesar 39,251 persen, dan pada tahun 2017 telah meningkat menjadi 39,298 persen (International Labour Organization, 2020) Begitu pula, terdapat peningkatan jumlah partisipasi wanita karier di Indonesia, pada tahun 2018 tercatat sejumlah 47,95 juta dan tahun 2019 menjadi 48,75 juta wanita yang bekerja (Badan Pusat Statistik, 2019). Peningkatan ini didorong dengan adanya gerakan emansipasi wanita sebagai landasan yang mendukung wanita agar tidak berperan hanya dalam urusan rumah tangga, namun juga dalam pekerjaan atau kariernya. Sehingga wanita juga memiliki kesempatan yang sepadan dengan laki-laki dalam dunia kerja. Bahkan sebagian besar peningkatan partisipasi karier tersebut disebabkan oleh adanya partisipasi wanita yang telah menikah (Ospina \& Tzvetkova, 2018).

Wanita karier yang telah menikah memiliki konsekuensi negatif yang menjadi permasalahan utama, yaitu adanya peran ganda dan beban kerja yang lebih. Peran ganda dalam wanita karier yaitu adanya peran domestik-reproduktif dan juga peran publik (Hidayati, 2015). Peran domestik-reproduktif seperti mengurus rumah tangga dan menjadi istri serta ibu bagi anak-anak. Sedangkan peran publikproduktif yaitu sebagai pekerja. Bahkan terkadang peran-peran tersebut bisa saling berbenturan satu sama lain. Selain itu, terdapat permasalahan terkait beban kerja yang dapat terjadi jika pembagian kerja tidak seimbang antara pria dan wanita sehingga menimbulkan beban kerja pada pihak yang terdominasi (Hidayati, 2015). Kondisi tersebut akan membuat wanita karier seringkali menghadapi tuntutan dari lingkungan. Wanita karier secara kodrat memiliki tuntutan agar bertanggung jawab dalam mengurus keluarga, sedangkan di sisi lain wanita karier sebagai pekerja juga dituntut untuk menunjukkan kinerja yang terbaik (Tewal \& Tewal, 2014). Peran dan beban tersebut bertambah terlebih saat terjadi pandemi COVID-19.

Adanya fenomena pandemic COVID-19 bukan hanya memiliki risiko terhadap kesehatan secara fisik namun juga membebani kesejahteraan individu secara mental (Hamouche, 2020), begitu pula pada wanita karier yang telah menikah. Para wanita karier menjadi lebih stres dan cemas karena dihadapkan pada bermacam-macam peran dan kegiatan yang multitasking (Marliani dkk., 2020). Wanita karier akan memikul beban yang lebih besar dibanding laki-laki dalam pengasuhan anak di tengah pandemi. Situasi saat ini menyebabkan adanya masalah kesehatan mental meliputi stres, cemas, marah, takut, depresi, bahkan insomnia. Masalah kesehatan mental ini tidak hanya mempengaruhi perhatian, pemahaman, dan pengambilan keputusan, tetapi juga bisa bertahan lama sehingga berpengaruh pada kesejahteraan secara keseluruhan (Handayani, 2020). Masalah yang mengkhawatirkan selama pandemi COVID-19 yaitu well-being wanita menjadi lebih rendah dibandingkan dengan laki-laki. Dalam penelitian ini akan membahas mengenai kesejahteraan terutama kesejahteraan mental atau bisa disebut mental well-being.

Mental well-being merupakan suatu hasil evaluasi seseorang mengenai pengalaman subjektif berupa kebahagiaan dan kepuasan hidup; serta adanya fungsi psikologis yang positif, hubungan baik dengan orang lain, dan self-realization (Brown, 2008). Mental well-being termasuk konstruk yang menggabungkan dua perspektif besar yaitu perspektif hedonic dan eudaimonic (Keyes, 2013). Perspektif hedonic atau subjective well-being yaitu keadaan di mana individu menilai terdapat afek-afek positif seperti kepuasaan dan kebahagiaan individu akan hidupnya dan ketiadaan afek-afek negatif seperti kecemasan, stres, kesedihan, dan sebagainya. Sehingga individu merasa baik (feeling good) akan kehidupannya (Diener \& Pavot, 1993). Sedangkan, perspektif eudaimonic atau psychological well-being yaitu merupakan kondisi di mana individu mempunyai sikap positif terhadap orang lain maupun diri sendiri, dapat mengambil keputusan serta mengatur tingkah laku, menciptakan dan mengatur 
lingkungan sesuai dengan kebutuhan, memiliki tujuan hidup, serta berusaha mengembangkan diri (Ryff, 1989).

Terdapat salah satu faktor yang mempengaruhi mental well-being yaitu regulasi diri. Regulasi diri merupakan keadaan individu dalam mengatur perilaku dan menjaga keseimbangan emosi agar tetap fokus pada apa yang sedang dikerjakan untuk mencapai tujuan (Schwarzer, 1999). Terdapat dua kriteria yang diperlukan agar individu dapat mempertahankan regulasi diri yang dimiliki, yaitu kemampuan individu untuk mengontrol dan menyesuaikan emosi yang timbul untuk mencapai suatu tujuan (emotional regulation) dan kemampuan untuk memfokuskan perhatian pada tugas-tugas yang diberikan, mengendalikan dan mengatur gangguan internal maupun eksternal, serta bekerja untuk menuju tujuan atau hasil yang diinginkan (attention regulation).

Menghadapi pandemi COVID-19 diperlukan adanya penerimaan diri serta memperkuat tujuan hidup guna mencegah penurunan well-being (Paryono, 2020). Memperkuat tujuan hidup dapat diperoleh dengan meningkatkan regulasi diri. Regulasi diri juga penting bagi wanita karier untuk mengelola stimulus negatif yang hadir dalam kehidupan dan tetap fokus pada tujuan mereka. Dengan adanya regulasi diri, maka wanita karier dapat menghadapi tuntutan yang muncul dalam waktu bersamaan. Regulasi diri merupakan hal penting bagi wanita karier karena kebanyakan wanita karier kurang dapat mengatur emosi saat dihadapkan pada suatu situasi yang tidak menyenangkan karena merasa tidak mampu menghadapi masalah yang ada. Wanita karier perlu memiliki regulasi diri agar dapat mengatur pikiran, perhatian, serta perhatiannya dalam menyelesaikan tugas dalam pekerjaan. Sedangkan wanita karier yang mengalami kegagalan dalam regulasi diri akan memenuhi tujuan jangka pendek dengan menunda pekerjaan (Prasad \& Chen, 2010). Bahari (2015) juga mengatakan bahwa kompleksnya tuntutan wanita bekerja dalam hal peran ganda dan adanya keinginan untuk menyeimbangkan antara keluarga dan pekerjaan dapat dilakukan dengan baik jika ia memiliki regulasi diri. wanita karier yang mengalami kegagalan dalam regulasi diri akan memenuhi tujuan jangka pendek dengan menunda pekerjaan dan merasa tertekan dengan banyaknya tuntutan.

Individu dengan regulasi diri yang tinggi akan membentuk suatu identitas dan komitmen yang kuat sehingga akan mendapatkan well-being yang tinggi. Sedangkan regulasi diri yang rendah akan membuat individu merasa kesulitan dalam memutuskan tindakan dalam situasi yang sulit (Hofer dkk., 2010). Simon \& Durand-Bush (2015) mengatakan bahwa adanya regulasi diri yang tinggi juga akan membuat individu dapat mengelola diri secara efektif dengan mempertahankan tujuan serta keseimbangan antara kehidupan kerja dengan kehidupan sehari-hari. Wanita karier akan lebih siap menghadapi tuntutan yang datang meskipun secara konsisten baik berasal dari lingkungan kerja maupun lingkungan keluarga, sehingga tercapai kesejahteraan dalam wanita karier yang menikah.

Selain itu, saat-saat pandemi memiliki kemungkinan-kemungkinan pada individu untuk merasa cemas terutama mengenai coronavirus dan berimbas pada penurunan mental well-being. Adapula faktor yang bisa menyebabkan tingkat well-being menjadi rendah yaitu timbulnya kecemasan atau anxiety (Smith dkk, 2020). Dalam saat seperti ini terdapat kecemasan-kecemasan yang muncul dikarenakan adanya pandemi COVID-19 yang dikenal dengan coronavirus anxiety. Coronavirus anxiety merupakan perasaan disfungsional yang terkait dengan virus corona (Lee, 2020).

Kecemasan-kecemasan yang dialami oleh wanita karier yang menikah terkait coronavirus dapat bermacam-macam bentuk. Seperti kecemasan fungsional atau merasa khawatir secara berlebihan baik dengan kondisi diri sendiri, keluarga, bahkan pekerjaan. Wanita karier juga mengalami kecemasan emosional yang dapat berupa ketakutan, gelisah, bahkan marah (Lee, 2020). Bahrami (2011) menyebutkan bahwa terdapat pikiran-pikiran metakognitif mengenai kekhawatiran yang tidak 
terkendali lebih banyak terjadi pada wanita dibanding pada laki-laki. Wanita diyakini memiliki kekhawatiran yang tidak terkontrol dan hal tersebut membuat wanita lebih mudah merasa cemas.

Smith pada tahun 2020 melakukan penelitian dan ditemukan bahwa terdapat adanya hubungan yang bersifat negatif dan signifikan antara coronavirus anxiety dengan mental well-being. Fenomena kecemasan akan pandemi bisa saja terulang kembali suatu saat nanti, sehingga kembali menimbulkan suatu kecemasan. Selain itu, dalam penelitian tersebut disebutkan bahwa kecemasan akan coronavirus pada wanita lebih besar dibandingkan pada laki-laki (Smith dkk., 2020). Perwira di tahun 2020 melanjutkan penelitian tersebut, ditemukan bahwa terdapat pengaruh antara coronavirus anxiety dengan well-being dengan arah negatif dan signifikan. Dengan tingginya well-being pada individu berarti bahwa individu cenderung merasa puas, bahagia, dan senang akan kehidupan yang dijalani. Sebaliknya, jika individu dengan well-being yang rendah akan cenderung memiliki pandangan negatif tentang kehidupan, dengan cenderung merasakan ketakutan, kecemasan, ataupun kesedihan (Perwira, 2020).

Tujuan dari penelitian ini untuk mengetahui pengaruh secara regulasi diri dan coronavirus anxiety terhadap mental well-being pada wanita karier yang menikah. Selain itu, penelitian ini juga bertujuan mencari seberapa besar regulasi diri dan coronavirus anxiety mampu memprediksikan tingkat mental well-being pada wanita karier yang menikah.

Secara terperinci hipotesis dalam penelitian ini meliputi:

H1: Terdapat pengaruh regulasi diri dan coronavirus anxiety terhadap mental well-being pada wanita karier yang menikah

H2: Terdapat pengaruh regulasi diri terhadap mental well-being pada wanita karier yang menikah

H3: Terdapat pengaruh coronavirus anxiety terhadap mental well-being pada wanita karier yang menikah

\section{E T O D E}

\section{Desain Penelitian}

Pendekatan yang digunakan dalam penelitian ini adalah pendekatan kuantitatif yang menghasilkan data dalam bentuk angka serta adanya uji hipotesis, proses analisis menggunakan statistik, diagram, ataupun tabel serta menggunakan prosedur-prosedur yang terstandar (Neuman, 2014). Jenis penelitian yang digunakan yaitu penelitian eksplanatori yang memiliki tujuan menguji akurasi dari suatu teori ataupun hipotesis tertentu guna memperkuat, memperkaya, menguraikan, atau menolak penjelasan dari teori ataupun hipotesis penelitian terdahulu. Terdapat beberapa teknik yang termasuk dalam metode penelitian kuantitatif, seperti survei, eksperimen, analisis konten, serta studi statistik. Berikutnya, teknik pengumpulan data menggunakan metode survei dengan media kuesioner (Neuman, 2014). Peneliti memilih metode tersebut karena sesuai dengan tujuan penelitian, yaitu untuk menjelaskan pengaruh dan pengujian hipotesis dari suatu fenomena yang diangkat.

\section{Partisipan}

Karakteristik target populasi yaitu seorang wanita yang bekerja dan telah memiliki ikatan pernikahan (sudah menikah). Sedangkan, karakteristik demografis yang digunakan meliputi tingkat pendidikan, usia subjek, usia pernikahan, jumlah anak, dan status pekerjaan. Peneliti menentukan sampling dengan menggunakan teknik non-probability sampling yaitu teknik yang membatasi sampel sehingga tidak semua memiliki kesempatan yang sama untuk menjadi sampel. Teknik ini juga digunakan karena 
adanya keterbatasan tenaga, waktu, serta uang. Dalam non-probability sampling salah satu metode yang digunakan peneliti adalah convenience sampling. Peneliti dapat memilih partisipan sesuai dengan kriteria. Peneliti menentukan jumlah sampel dengan perhitungan $G^{*}$ Power 3.1 dengan level signifikansi sebesar 0,05 serta level power sebesar 0,95. Hasil hitung $G^{*}$ Power menunjukkan bahwa minimum dalam penelitian sampel yang dibutuhkan yaitu 74 partisipan.

\section{Teknik Pengumpulan Data}

Penelitian ini menggunakan teknik pengumpulan data berupa survei dengan media kuesioner menggunakan skala likert untuk masing-masing variabelnya dan disebarkan kepada subjek melalui tautan lime survey. Menurut Neuman (2014) survei adalah teknik mengumpulkan data yang paling banyak digunakan oleh peneliti. Begitu pula, skala likert juga merupakan skala yang paling sering digunakan untuk survei. Sedangkan, kuesioner adalah bentuk instrumen pengumpulan data yang relatif mudah untuk digunakan dan sangat fleksibel (Azwar, 2017). Dalam penelitian ini juga terdapat kuesioner yang berisi informed consent, sehingga partisipan mengisi kesediaan mengisi kuesioner dengan keadaan sadar dan tidak terpaksa.

\section{Pengukuran}

Alat ukur yang dipergunakan untuk variabel regulasi diri adalah alat ukur hasil adaptasi dari Rustandi (2016) yang disebut Self-Regulation Scale. Terdiri dari 10 item dengan 4 pilihan jawaban (1="sangat tidak setuju" hingga 4="sangat setuju"), dengan koefisien reliabilitas sebesar 0,77. Alat ukur tersebut menggunakan teori regulasi diri diadaptasi dari Schwarzer dkk (1999) yang memiliki dua dimensi yaitu emotional regulation dan attention regulation.

Alat ukur yang digunakan pada variabel coronavirus anxiety merupakan alat ukur Lee (2020) yang berjumlah 5 item dengan koefisien reliabilitas sebesar 0,93. Terdiri dari 5 pilihan jawaban (1="tidak sama sekali", 2="jarang", 3="beberapa hari", 4="lebih dari tujuh hari", dan 5 = "hampir setiap hari").

Alat ukur yang digunakan pada variabel mental well-being merupakan alat ukur adaptasi dari penelitian Wicaksono (2018) berjumlah 14 item. Menggunakan teori mental well-being dari Brown (2008) dan setelah memiliki koefisien reliabilitas sebesar 0,91 . Terdapat 5 pilihan jawaban $(1=$ "tidak pernah sama sekali", hingga 5="setiap waktu").

\section{Analisis Data}

Tipe penelitian ini adalah kuantitatif yang akan mendapatkan hasil penelitian berupa data. Sehingga perlu menggunakan analisis statistik yang berfungsi untuk mengolah data yang telah diperoleh. Peneliti menggunakan teknik analisis data untuk menguji pengaruh regulasi diri $\left(\mathrm{X}_{1}\right)$ dan coronavirus anxiety $\left(\mathrm{X}_{2}\right)$ terhadap mental well-being $(\mathrm{Y})$, uji regresi dengan metode analisis regresi linear berganda. Penghitungan analisis data menggunakan program IBM SPSS versi 22.0 for Windows.

\section{HAS I L P E N E L I T I A N}

\section{Analisis Deskriptif}

Penelitian ini memperoleh sebanyak 107 partisipan dengan nilai mean berarti rata-rata dari variabel tersebut yaitu regulasi diri sebesar, 27,74, coronavirus anxiety sebesar 6,36, dan mental well-being sebesar 54,27. Berikutnya, standar deviasi menunjukkan jarak penyimpangan antar skor dan nilai mean. Nilai minimum berarti nilai terendah dari variabel, sebaliknya terdapat nilai maksimum yang menunjukkan nilai tertinggi, dan range berarti selisih antara nilai maksimum dengan nilai minimum, 
Kemudian, terdapat nilai skewness yang menunjukkan indikasi simetri dari distribusi data. Diketahui bahwa nilai skewness variabel regulasi diri dan variabel coronavirus anxiety sebesar 0,125 dan 1,478 menunjukkan bahwa data mengumpul atau condong ke arah kiri. Sedangkan, nilai skewness variabel mental well-being sebesar -0,779 menunjukkan bahwa data condong ke arah kanan. Nilai kurtosis menunjukkan puncak distribusi data. Kurtosis yang positif menunjukkan bahwa distribusi data memuncak dan berkerumun di tengah. Sedangkan nilai kurtosis negatif berarti menunjukkan adanya distribusi data yang relatif rata (Pallant, 2001). Nilai kurtosis variabel regulasi diri 0,337, coronavirus anxiety 1,863, dan mental well-being 1,184 yang menunjukkan nilai positif dan berarti data cenderung memuncak.

\section{Uji Asumsi}

Penelitian ini menggunakan beberapa Langkah untuk uji asumsi. Pertama, uji normalitas dilakukan guna mengetahui adanya persebaran data dan meneuntukan teknik analisis yang akan dilakukan. Uji normalitas menentukan data yang dimiliki berdistribusi normal atau tidak normal (Pallant, 2001). nilai signifikansi yaitu sebesar $(p=0,2)$ memiliki arti bahwa data berdistribusi normal karena memiliki nilai $(p>0,05)$. Kemudian terdapat uji linearitas guna mengetahui kecenderungan hubungan antar variabel. Jika terdapat kecenderungan hubungan antar variabel maka akan membentuk garis linear. Hubungan variabel dapat dikatakan linear apabila nilai $(p<0,05)$. Nilai signifikansi variabel regulasi diri dengan mental well-being adalah $(p=0,000)$ dan coronavirus anxiety dengan mental well-being adalah $(p=0,011)$. Dengan demikian, dapat disimpulkan bahwa terdapat hubungan yang linear antara variabel-variabel $\mathrm{X}$ dengan variabel Y pada penelitian ini. Selanjutnya, uji multikolinearitas dilakukan guna mengetahui korelasi antara dua variabel bebas yang dimiliki. Model regresi yang baik seharusnya terbebas dari multikolinearitas dan dilihat dari besarnya nilai Tolerance $>0,1$ atau nilai VIF $<10$ (Pallant, 2001). Nilai tolerance variabel regulasi diri dan coronavirus anxiety sebesar (Tolerance $=0,991)$ dan nilai VIF sebesar (VIF $=1,009$ ). Oleh karena itu, dapat ditarik kesimpulan bahwa tidak terjadi adanya multikolinearitas pada model regresi tersebut dan kedua variabel bebas tidak saling berhubungan. Kemudian, uji homoskedastisitas dilakukan dengan hasil jika titik-titik membentuk pola tertentu maka data terindikasi adanya heteroskedastisitas. Namun, jika data tidak terdapat pola tertentu maka berarti tidak terjadi heteroskedastisitas dan terjadi homoskedastisitas. Dilihat dari hasil uji, titik-titik yang dihasilkan menyebar serta tidak membentuk pola tertentu. Dengan demikian, diambil kesimpulkan bahwa model regresi tersebut memenuhi asumsi homoskedastisitas.

\section{Uji Korelasi}

Uji korelasi berguna mengetahui kekuatan dan arah hubungan antar variabel. Arah hubungan ditunjukkan dengan positif atau negatif, sedangkan kekuatan hubungan ditunjukkan dengan angka signifikansi. bahwa variabel regulasi diri dengan mental well-being memiliki korelasi yang sedang dan positif yaitu sebesar 0,473 . Selanjutnya variabel coronavirus anxiety dengan mental well-being memiliki korelasi yang rendah dan negatif yaitu sebesar -0,236. Artinya, ketika regulasi diri meningkat, maka mental well-being juga ikut meningkat. Namun sebaliknya, ketika coronavirus anxiety meningkat, maka mental well-being akan menurun.

\section{Uji Regresi Berganda}

Penelitian ini melakukan Uji regresi linear berguna untuk mengetahui pengaruh variabel regulasi diri dan coronavirus anxiety terhadap mental well-being secara simultan. Dihasilkan nilai $(\mathrm{F}=18,398$, $p=0,000, \mathrm{R}^{2}=0,261$ ). Maka dapat diambil simpulan bahwa persentase pengaruh variabel regulasi diri dan coronavirus anxiety sebesar $26,1 \%$ terhadap variabel mental well-being dan sebesar $73,9 \%$ berasal dari variabel-variabel lainnya yang tidak diteliti. Sedangkan jika dilakukan uji regresi berganda secara 
parsial maka didapatkan hasil bahwa pengaruh regulasi diri terhadap mental well-being yaitu $(p=0,000$ dan $\mathrm{R}^{2}=0,224$ ). Sehingga dapat disimpulkan bahwa persentase pengaruh regulasi diri terhadap mental well-being yaitu sebesar $22,4 \%$. Pengaruh variabel coronavirus anxiety terhadap mental well-being yaitu $\left(p=0,024\right.$ dan $\left.\mathrm{R}^{2}=0,056\right)$. Maka, dapat disimpulkan bahwa coronavirus anxiety mempunyai persentase pengaruh sebesar $5,6 \%$. Seluruh uji yang dilakukan dalam penelitian ini menggunakan bantuan IBM SPSS 22 for Windows.

\section{I S K U S I}

Regulasi diri dan coronavirus anxiety bersama-sama dapat mempengaruhi mental well-being. Dalam penelitian ini, pengaruh yang dihasilkan yaitu 26,1 persen. Hal tersebut sesuai dengan penelitian Marliani dkk (2020) yang menjelaskan bahwa regulasi diri dan anxiety, keduanya secara bersamaan dapat mempengaruhi perilaku dan kesejahteraan individu. Regulasi diri memiliki pengaruh positif yang berarti bahwa semakin tinggi tingkat regulasi pada wanita karier yang menikah maka semakin tinggi mental well-being yang ada dalam dirinya. Kemudian, pengaruh coronavirus anxiety bersifat negatif yang berarti semakin tinggi coronavirus anxiety maka semakin rendah mental well-being pada wanita karier yang menikah.

Adanya pengaruh yang signifikan antara regulasi diri terhadap mental well-being yaitu sebesar 22,4 persen. Sesuai dengan penelitian Simon \& Durand-Bush (2015) yang mendapatkan hasil bahwa regulasi diri memiliki hubungan yang kuat dengan well-being, dilihat dari adanya regulasi diri yang berfokus kepada kemampuan mengelola emosi serta fokus agar sesuai dengan tujuan yang diinginkan. Sesuai dengan apa yang ada dalam perspektif hedonic dalam mental well-being yaitu kesejahteraan akan didapatkan jika individu mengetahui tujuan hidup serta dapat menyeimbangkan lingkungannya. Simon \& Durand-Bush (2015) juga mengatakan bahwa regulasi diri memiliki pengaruh kuat dengan faktor tujuan hidup (purpose in life) serta faktor penguasaan lingkungan (environmental mastery) dalam wellbeing. Sehingga regulasi diri memiliki pengaruh terhadap mental well-being.

Dilihat dari dimensi yang ada dalam regulasi diri, hasil penelitian ini menunjukkan bahwa dimensi emotional regulation memiliki pengaruh lebih besar dibandingkan dengan attention regulation. Menurut penelitian Marliani dkk (2020) regulasi emosi dianggap sebagai salah satu dari aspek personal bagi seorang wanita karier yang berperan dalam meningkatkan kesejahteraan. Seorang wanita karier yang mampu menempatkan emosi sesuai dengan kondisinya maka dapat meningkatkan kebahagiaan mereka. Serta kemampuan meregulasi emosi yang baik dapat membuat proses berinteraksi menjadi lebih efektif antara wanita karier dengan keluarga maupun lingkungan sekitarnya. Selain itu terdapat penelitian terdahulu yang mengatakan bahwa emotional regulation lebih memiliki pengaruh daripada attention regulation. Namun, pada dasarnya pencapaian tujuan membutuhkan integrasi dan regulasi dari adanya emotional regulation maupun attention regulation (Valikhani dkk., 2019).

Hasil penelitian menyatakan bahwa coronavirus anxiety memiliki pengaruh terhadap mental well-being. Sesuai dengan penelitian (Smith dkk, 2020) menyebutkan bahwa terdapat hubungan maupun pengaruh dari coronavirus anxiety dengan mental well-being. Disebutkan bahwa mental well-being yang buruk secara signifikan cenderung terdapat pada partisipan wanita. Kecemasan terhadap coronavirus juga terjadi akibat adanya peran tambahan dan beban berlebih pada wanita karier yang menikah seperti menjadi guru pendamping bagi anak untuk learn from home, memastikan bahwa keluarga sehat dan tetap menjalankan protokol kesehatan, dan adaptasi tambahan untuk pekerjaannya di kala pandemi yang langsung maupun tidak langsung juga ikut terdampak (Handayani, 2020). 
Namun, hasil yang ditemukan pada penelitian ini menyebutkan bahwa pengaruh coronavirus anxiety terhadap mental well-being memberikan kontribusi yang sedikit yaitu hanya 5,6 persen dan berarti memiliki hubungan yang lemah. Hal tersebut dijelaskan oleh Lembaga Lingkaran Survei Indonesia (LSI, 2020) yang menemukan lima alasan kecemasan terkait COVID-19 atau coronavirus anxiety menurun. Pertama, adanya beberapa negara yang sukses mengendalikan grafik virus corona. Kedua, terdapat beberapa kebiasaan-kebiasaan baik terkait dengan protokol kesehatan yang telah dijalankan oleh seluruh masyarakat, seperti memakai masker, selalu mencuci tangan, dan social distancing. Ketiga, tabungan terkait ekonomi semakin menipis, sehingga pada saat ini kecemasan terkait COVID-19 menurun sedangkan kecemasan terkait ekonomi meningkat. Keempat, jumlahnya masyarakat yang terpapar virus corona jauh lebih sedikit daripada yang terkena dampak ekonomi. Dan kelima, hingga kini grafik yang terpapar corona semakin landai dan menurun sehingga membuat kecemasan terkait COVID-19 juga menurun.

\section{S I M P U L A N}

Dilihat dari analisis data yang telah dilakukan, maka dapat ditarik simpulan bahwa terdapat adanya pengaruh yang signifikan antara regulasi diri dan coronavirus anxiety terhadap mental well-being pada wanita karier yang menikah, baik secara simultan maupun parsial. Saran untuk penelitian selanjutnya lebih mempertimbangkan karakteristik partisipan, karena semakin jelas dan terarah akan memberikan hasil yang lebih maksimal. Selain itu, saran bagi perusahaan diharapkan lebih memperhatikan keselamatan dan kesejahteraan pekerja sehingga dapat menurunkan kecemasan terkait coronavirus. Hal yang dapat dilakukan meliputi penerapan perilaku 3M (mencuci tangan, menjaga jarak, serta menggunakan masker) guna meminimalisir adanya penyebaran COVID-19. Serta dapat membantu wanita karier yang menikah untuk mengembangkan regulasi dirinya melalui intervensi pelatihan. Misalnya, konseling kelompok serta workshop manajemen waktu (Wijaya \& Nashori, 2015).

Sedangkan, wanita karier dapat menjalin hubungan secara periodik dan regular, menjalin komunikasi dengan orang lain, atau memiliki support group. Hal tersebut sebagai adanya dukungan sosial sehingga wanita karier yang menikah tidak merasa sendiri dalam menjalankan perannya (Ikawati, 2018). Wanita karier juga dapat mengatasi kecemasan terkait COVID-19 dengan menyeleksi informasi mengenai pandemi, meminta bantuan kepada keluarga dan orang terdekat jika merasakan cemas atau afek-afek negatif lainnya, serta meminta bantuan praktisi kesehatan mental secara daring seperti HIMPSI atau klinik kesehatan lainnya jika merasakan gejala gangguan mental khususnya terkait coronavirus (Vibriyanti, 2020)

\section{U C A P A N T E R IMAKASIH}

Penulis berterima kasih kepada para partisipan yang berkenan membantu penelitian sehingga dapat terselesaikan dengan baik. Dan semoga penelitian ini dapat berguna bagi wanita karier yang menikah, perusahaan, dan juga peneliti selanjutnya.

\section{DEKLARASI POTENSI TERJADINYA KONFLIK KEPENTINGAN}

Laili Faristin Sukma dan Herison Pandapotan Putra tidak bekerja, menjadi konsultan, memiliki saham, atau menerima dana dari perusahaan atau organisasi manapun yang mungkin akan mengambil untung dari diterbitkannya naskah ini. 


\section{PUSTAKA ACUAN}

Bahari, C. S. A. (2015). Regulasi Diri Dalam Mengatasi Konflik Peran Ganda Pada Wanita Berkeluarga Yang Bekerja Sebagai Manajer. Skripsi Thesis.

Bahrami, N., DordiNejad, F. G., Hakimi, H., Ashouri, M., Dehghani, M., Zeinali, Z., \& Daghighi, M. S. (2011). On the relationship between test anxiety and academic performance. Procedia - Social and Behavioral Sciences, 15, 3774-3778. https://doi.org/10.1016/j.sbspro.2011.04.372

Brown, S. S. (2008). Using and analysing WEMWBS to measure the impact of interventions in improving mental wellbeing. 1-25.

Diener, E., \& Pavot, W. (1993). Review of the Satisfaction With Life Scale. Psychological Assessment, Vol. 5, pp. 164-172. https://doi.org/10.1093/geront/16.1_part_2.70

Hamouche, S. (2020). COVID-19 and employees' mental health: stressors, moderators and agenda for organizational actions. 15. Retrieved from https://emeraldopenresearch.com/articles/2-15

Handayani, M. R. D. (2020). Psychological Well Being Wanita Karir saat Work From Home pada Masa Pandemi COVID-19.

Handayani, R. (2020). Multi Peran Wanita Karir Pada Masa Pandemi Covid-19. Jurnal Kajian Gender Dan Anak, 04(1), 1-10.

Hidayati, N. (2015). Beban Ganda Perempuan Bekerja (Antara Domestik dan Publik). Muwazah, 7(2), 108-119. $\quad$ Retrieved from http://ejournal.iainpekalongan.ac.id/index.php/Muwazah/article/view/516

Hofer, J., Busch, H., \& Kärtner, J. (2010). Self-regulation and well-being: The influence of identity and motives. https://doi.org/10.1002/per

Ikawati. (2018). Family Social Services to Conflict Preventive of Women. 213-224.

Keyes, C. (2013). Promoting and protecting positive mental health: Early and often throughout the lifespan. In Mental Well-Being: International Contributions to the Study of Positive Mental Health. https://doi.org/10.1007/978-94-007-5195-8_1

Lee, S. A. (2020). Coronavirus Anxiety Scale: A brief mental health screener for COVID-19 related anxiety. Death Studies, 44(7), 393-401. https://doi.org/10.1080/07481187.2020.1748481

Marliani, R., Nasrudin, E., Rahmawati, R., \& Ramdani, Z. (2020). Regulasi Emosi , Stres , dan Kesejahteraan Psikologis : Studi Pada Ibu Work from Home dalam Menghadapi Pandemi COVID19. Jurnal Psikologi, (1).

Neuman, W. L. (2014). Social Research Methods: Qualitative and Quantitative Approaches. In Teaching Sociology (Vol. 30). https://doi.org/10.2307/3211488

Organization, I. L. (2020). Labour Force, Female. Retrieved from ILOSTAT Database website: https://data.worldbank.org/indicator/SL.TLF.TOTL.FE.ZS

Ospina, E. O., \& Tzvetkova, S. (2018). Women's employment. Our World in Data. Retrieved from https://ourworldindata.org/female-labor-supply

Pallant, J. (2001). SPSS survival manual. In Chicago/Illinois USA: SPSS Inc/223.wackerdrive/.

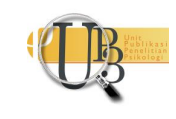


https://doi.org/10.4324/9781003117407

Paryono, H. Y. (2020). Faktor Risiko dan Resiliensi Psikologis Pandemi COVID-19 di Indonesia Employees ' Psychological Well -Being, Before and During COVID-19 Pandemic: A Case Study in Nutrifood Indonesia Herman Yosef Paryono, S. Psi ., M. Sc . (June).

Perwira, A. Y. (2020). Hubungan antara Kecemasan Menghadapi Wabah COVID-19 dengan Subjective Well Being pada Mahasiswa Lampung yang Kuliah di Surabaya. Undergraduate Thesis.

Prasad, S., \& Chen, D. J. Q. (2010). Self-Regulation, Individual Characteristics and Cyberloafing. PACIS Proceedings, 159.

Rustandi, F. D. (2016). Pengaruh Regulasi Diri Terhadap Perilaku Cyberloafing Pada Karyawan di Kota Bandung. (1205218).

Ryff, C. D. (1989). Happiness Is Everything, or Is It? Explorations on the Meaning of Psychological WellBeing. American Journal of Managed Care, 57(6), 1069-1081.

Schwarzer, R. (1999). Self-Regulation Scale. Berlin: NCBI.

Simon, C. R., \& Durand-Bush, N. (2015). Does self-regulation capacity predict psychological well-being in physicians? Psychology, Health and Medicine, 20(3), 311-321. https://doi.org/10.1080/13548506.2014.936887

Smith, L., Jacob, L., Yakkundi, A., McDermott, D., Armstrong, N. C., Barnett, Y., ... Tully, M. A. (2020). Correlates of symptoms of anxiety and depression and mental wellbeing associated with COVID19: a cross-sectional study of UK-based respondents. Psychiatry Research, 291(May), 113138. https://doi.org/10.1016/j.psychres.2020.113138

Statistik, B. P. (2019). Tingkat Partisipasi Tenaga Kerja. Retrieved from https://databoks.katadata.co.id/datapublish/2019/05/07/tingkat-partisipasi-tenaga-kerjamasih-didominasi-laki-laki

Tewal, F., \& Tewal, B. (2014). Pengaruh Konflik Peran Terhadap Kinerja Wanita Karir Pada Universitas Sam Ratulangi Manado. Jurnal Riset Ekonomi, Manajemen, Bisnis Dan Akuntansi, 2(1). https://doi.org/10.35794/emba.v2i1.4020

Valikhani, A., Goodarzi, M. A., \& Hashemi, R. (2019). Psychometric Properties of Dispositional SelfRegulation Scale in Iranian Population and Predicting Inhibitory/Initiatory Self-Control on the Basis of It. Current Psychology, 38(1), 154-164. https://doi.org/10.1007/s12144-017-9574-z

Vibriyanti, D. (2020). Kesehatan Mental Masyarakat: Mengelola Kecemasan Di Tengah Pandemi Covid19. Jurnal Kependudukan Indonesia, 2902, 69. https://doi.org/10.14203/jki.v0i0.550

Wicaksono, D. A. (2018). Internal Validation of the Warwick-Edinburgh Mental Wellbeing Scale: Rasch Analysis in the Indonesian Context.

Wijaya, H. E., \& Nashori, F. (2015). Efektivitas Pelatihan Regulasi Diri Untuk Menurunkan Prokrastinasi Mahasiswa Dalam Mengerjakan Skripsi. Jurnal Intervensi Psikologi (JIP), Vol. 7, pp. 79-96. https://doi.org/10.20885/intervensipsikologi.vol7.iss1.art6 